\title{
Parks' Governance and Management in Rwanda: Opportunities and Challenges of the Community Participation for a Sustainable Conservation - Case Study of Nyungwe National Park
}

\author{
Gloriose Umuziranenge \\ Department of Natural Resources and Environment Management, Protestant Institute of Arts and Social Science, Huye, Rwanda
}

Email address:

gloris06@yahoo.fr

\section{To cite this article:}

Gloriose Umuziranenge. Parks' Governance and Management in Rwanda: Opportunities and Challenges of the Community Participation for a Sustainable Conservation - Case Study of Nyungwe National Park. International Journal of Environmental Protection and Policy. Vol. 7, No. 2, 2019, pp. 61-71. doi: 10.11648/j.ijepp.20190702.13

Received: February 26, 2019; Accepted: April 2, 2019; Published: May 10, 2019

\begin{abstract}
In the field of conservation, the shift from the fortress conservation approach towards participatory management has considerably increased the interest for tourism activities and income. In Rwanda, the protected areas governance system is promoting community-based conservation through tourism revenue sharing to achieve conservation and development goals. The case study was designed to: (1) assess the understanding and implementation of principles of community participation by different stakeholders for the benefit of local communities and the efficiency of the conservation and (2) define interactive dynamics and conditions created for fully and sustainably population involvement in the conservation. The study area was selected because of its rich biodiversity and the high dependence of surrounding populations on natural resources. The study adopted a qualitative approach based on semi-structured individual interviews to key stakeholders from different categories of stakeholders including local communities. The data collected were transcribed, translated and analyzed using content analysis methods, MAXQDA Software and a coding system. The results showed that the involvement and empowerment of local people are done through keen activities based cooperative associations and funded projects, reference made to resources use, awareness raising and skills for interactions, cooperative spirit promotion and entrepreneurship. They indicated that the level of communities' participation remains only of procedural kind and is still low though community members are benefiting of jobs, loans for their projects and income generating activities such as organized productions for market thanks to tourism revenue sharing and revolving fund programs. The transfer of the management is slow and smooth because of a slow change of mindset from receiving mentality, farming related difficulties, unaffordable lending conditions and a great deal of communication and misunderstanding on the tourism revenue sharing and the projects funding approaches. Contradictory understandings and appreciations of the community participation are recorded according to the categories of stakeholders. Actually, all the administrative and technical processes including mediation between communities and funding agencies are driven through a top-down management model; the study area being a state owned and controlled park and not a co-managed one. Though local communities gradually understand the role of the park thanks to income generating activities and community projects, the new approach does not meet basic criteria for effective community participation to ensure the sustainability of the conservation. However, the socio-economic incentives have a positive impact on the reduction of illegal activities and threats, except poaching for which a compensation fund for damaged crops was created.
\end{abstract}

Keywords: Nyungwe National Park, Community Participation, Natural Resources Management, Tourism Revenue Sharing, Rwanda 


\section{Introduction}

Historically, the nature conservation paradigm started within the protectionism approach which denied the local communities to participate in conservation activities and people to use protected natural resources for their basic needs [1]. For a long time, the approach was perceived as the best one to achieve nature conservation [2]. In Africa and in Rwanda, it expanded so quickly that local livelihood strategies and activities like farming activities, cattle grazing and hunting were declared as illegal [3].

In protected areas which were delimited and placed under state control, customary rights were ignored [4] and human impact was monitored. The protectionism approach failed to achieve its goals for many reasons among which a high reliance of local communities to natural resources and a high rate of poverty $[5,6]$. In the 1980 's, a new conservation approach called "People-centred conservation", "Community based conservation" or "Participatory approach" [7, 8] appeared with the aim of reconciling conservation and local development [9] by involving local people in sharing the financial benefits of projects and in the total process of natural resource management. In recent years, different models of "community based conservation" programs (CBC) linking the conservation to the alleviation of rural poverty through socio-economic welfare initiatives and community participation were undertaken [10], especially in favor of previously neglected people around protected areas [11].

These experiences of co-management and bottom up approach in policy making [2, 12, 13] are being constrained by inadequate government resources, weak management capacities and ineffective legal systems [14]. The values and processes of community based conservation cannot be achieved without education, awareness raising, community mobilization and job creation that allow people to increase knowledge and capabilities to influence decisions [15]. Actually, local communities are often involved at a stage of implementation, not in the whole process like project identification, preparation, monitoring and evaluation [16, $17,18,19,20]$.

The success of the community participation depends on how it considers the new power relations and inclusivity [21]. In Rwanda, this conservation approach was promoted for the following reasons: (1) the country has the highest population density in Africa which is 350 people $/ \mathrm{km}^{2}$ [22], (2) over $90 \%$ of the population is engaged in subsistence agriculture, (3) natural resources such as forests, land and water are vital to country individuals' occupations [23] and (4) people living inside and around protected areas are among the poorest citizens and bring increased pressure and degradation [24].

Since 1998, indeed, a decentralization policy aiming at ensuring democratic governance, accountability and local community participation in decision making was adopted. Community participation was envisioned as one of the benefits of decentralization as citizens sought greater input in matters affecting them [25]. In the field of nature conservation, an organic law was voted in 2005 for the management and utilization of protected areas and environmental resources [26] involving local communities, local authorities, public and private institutions and Non Governmental Organizations (NGOs). Given the great potential and the quick growth of eco-tourism industry in terms of revenues, many people including decision makers believe that the tourism sector can better help to achieve socio-economic development at local community level.

The new law and management scheme and related regulations were entrusted in Rwanda Development Board (RDB). The Rwandan Office of Tourism and National Parks (ORTPN) started a tourism income sharing plan whereby 5\% of the aggregate Gross Revenue is gathered into a national pool and appropriated to the parks at various proportions: $40 \%$ to Volcano National Park, 30\% to Akagera National Park and 30\% to Nyungwe National Park [27]. Since 2017, the funds available to support the revenue share program increased from $5 \%$ to $10 \%$ of all tourism revenue. The amount goes back to the communities surrounding the 3 national parks. The Tourism Revenue Sharing is intended to induce local population's ownership and benefit from those parks.

The program assists local communities living adjacent to national parks in the construction of infrastructures like schools, dispensaries, water supply, food security and other income generating activities [28]. Through the program, RDB supports projects that benefit development and welfare of local communities and involves them in conservation activities, including being park rangers and guides of the parks. The scheme is conducted through cooperatives starting from people who were involved in illegal activities from the past. From 2005 to 2018 , over US\$1.28 million has been spent on more than 158 community-based projects in three main national parks mentioned above. However, little is known about the community perceptions towards their involvement in Tourism Revenue Sharing scheme administrated by Rwanda Development Board (RDB).

The present study aimed to examine the community participation in natural resources management by focusing on: (1) how communities understand community participation approach, (2) how they are empowered to participate in conservation, understanding the benefits that they could receive as neighbors of protected areas, challenges that hinder them in participating in natural resources management and strategies to overcome those challenges. It intended to investigate whether during the implementation of the law's new provisions, the involvement of local community is genuinely and professionally done both to meet the expectations of the community and to achieve its purposes.

As specific goals, it aims to: (1) assess how participation as a tool of good governance in conservation and natural resources management is understood and perceived by the community around national parks, (2) identify the challenges that hinder them to participate fully and efficiently in the management of national parks and (3) suggest ways for improvement of the community participation in the 
conservation and the management of national parks. Given its ecological importance as a mountainous rainforest and the great surrounding pressures and degradation, the Nyungwe National Park (NNP) was chosen to be the study area considering a period of 13 years running from 2005 when the new management system was set up to 2018 .

\section{Methodology}

\subsection{Study Area}

The Nyungwe National Park (NNP) is one of the three national parks of Rwanda. It is located in South West of the Country. It is surrounded by 4 Districts that are Nyamasheke, Rusizi Nyaruguru and Nyamagabe as indicated in Figure 1 and 36 Sectors. NNP resulted from the erection of the former Nyungwe Natural Forest Reserve under the law $n^{\circ} 22 / 2005$ of November 21, 2005 setting up new management schemes which prevent different activities by many different groups to stop.

The Park includes Cyamudongo and Gisakura Natural Forests. Until 2005, it is the Wildlife Conservation Society (WCS) that was in charge of the full management of the Nyungwe Natural Reserve. The NNP is a high-altitude mountainous rainforest along the Albertine Rift covering approximately $1,019 \mathrm{~km}^{2}$. It is the largest mountainous forest remaining in Africa and home to $20 \%$ of all African primates, including 13 primate species, as well as 280 bird species including 25 endemic ones; 43 species of reptiles, and 85 mammal species. The Park is also characterized by an extremely rich plant life with more than 240 species of orchids.

The NNP surrounding zones are very populated with a more or less 300 occupants $/ \mathrm{km}^{2}$. More than $90 \%$ of the local communities are subsistence farmers having an average cultivated area of less than 1 ha per household. Thanks to its important biodiversity, the NNP plays a big role in the surviving of the neighboring communities. It provides many ecosystemic services by means of water catchments for most of the communities and balances out soil disintegration and erosion for the surrounding communities. In terms of ecotourism, NNP is currently the second most prevalent nature based tourism fascination in Rwanda after the Volcano National Park. Guided strolls, chimpanzee following and recreational offices from Lake Kivu in this manner make the NNP special.

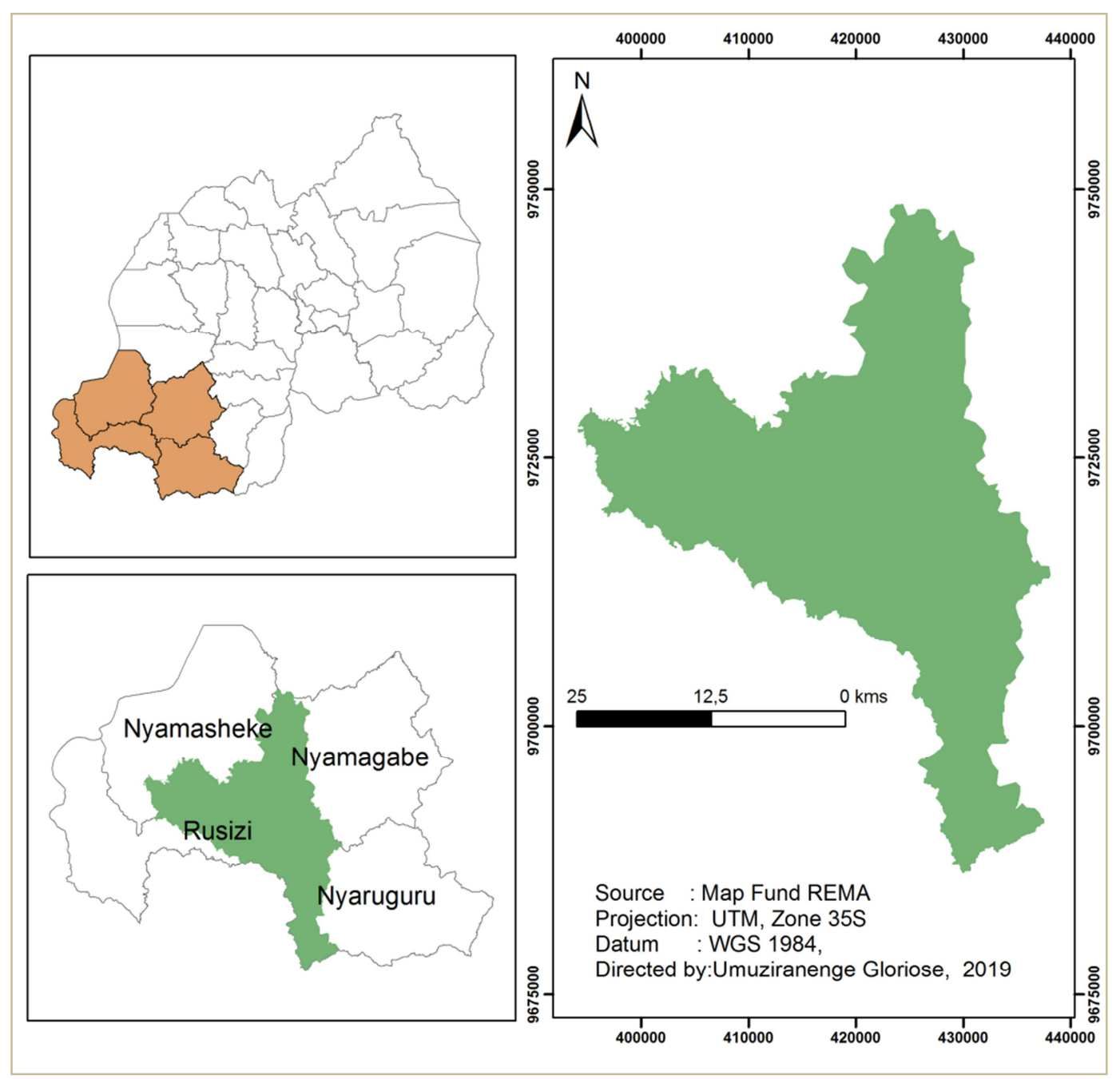

Figure 1. Localization map of the Nyungwe National Park. 
Since a long time tea plantations and mining activities are organized by internal villages where people were used to come for businesses and would degrade the forest [26]. Until the early 1990 's, more than 3.000 people were permanently living in the park and had built houses and shops in places like Pindura and Karamba [29]. The main challenges that NNP is facing are: (1) the increased population pressure, (2) a high rate of poverty of the surrounding populations, (3) a high reliance on natural resources, especially on agriculture for livelihoods, (4) important forest and bush fires, (5) hunting pressures on largest mammals, (6) artisanal and industrial mining and (7) deforestation for firewood, medicine, grass for cattle and construction materials [24, 30].

Around 360,000 people specifically fringe the recreation center. The main human threats to biodiversity include poaching, deforestation, bush fires, honey collection and mining activities [31]. These threats resulted in the disappearance of large mammals like elephants (Loxodonta africana) and buffalos (Syncerus caffer). The high percentage of poor and low educated people living around NNP is a big challenge for both tourism and conservation development [24].

\subsection{Research Approach and Methods}

The study started with secondary data collection and analysis. These ones were obtained through the literature available, annual reports and internet sources. In order to explore and take into consideration different views on the research issues, qualitative approach was adopted because it fits the purpose of the present study. With regard to sampling, theoretical and purposive samplings were used to progressively selected participants.

Five professional groups or stakeholders were selected for the study. Data collection relied on interview guides to members of communities and to key informants from public and private institutions. The participants to interviews were chosen among 5 categories: (1) conservation NGOs, (2) community leaders, (3) associations involved in Tourism and Conservation activities, (4) government officers in charge of conservation activities and (5) members of local community at associations' level including former miners, former poachers, artisans and beekeepers association around Kitabi and Nshili zones today.

Key interviews were conducted to further collecting full information. The individual interviewed are leaders of or from institutions like RDB, Wildlife Conservation Society (WCS), District Environmental Officers, NGO participating in community empowerment through training and loans for community projects, leaders of community associations, local leaders and district local government leaders. To approach the question about different stakeholders' views on community participation, semi-structured interviews were conducted to allow the interviewees the opportunity to express their personal experiences or views in their own words, which in turn allows the interviewer to gain the interviewee's perspective [32].

Therefore the research adopted a qualitative approach to gather the required primary data through individual semistructured interviews. In practice, qualitative approach is preferred when one seeks to explore how individuals interpret their experiences on a given matter [33, 34]. It focuses on understanding people's beliefs, perspectives, experiences, attitudes, opinions, perceptions about phenomena and situations or issues [35]. Participants for interviews during data collection were community leaders and community associations that were selected conveniently considering the one ready to be interviewed.

The key interviewed respondents were selected purposively based on their experience in working with the community and they include leaders in institutions like Rwanda Development Board (RDB), the Wildlife Conservation Society (WCS); the District environmental officers; the NGOS participating in community empowerment through training and loans for community projects; leader of community associations; local leaders and District local government leaders. For sampling techniques this research used a theoretical sampling where the choice of participants, data collection and analysis are done in parallel [33].

In this process, the size of the sample is not fixed. Rather, the sample size is determined by the saturation point when no new information is coming out $[33,34]$. The respondents of different categories were as interesting as they could present and explain official policies. Audio recording and notes taking were used for interviews. To ensure and promote privacy and confidentiality of the participants, each of them was assigned a code at the beginning of the interview. At the end, 20 participants representing different stakeholder groups were selected according to the repartition shown in Table 1.

Table 1. Repartition of the participants to interviews.

\begin{tabular}{lll}
\hline Category of Stakeholders & Institutions & Number of Participants \\
\hline 1. Local Communities & Park's surrounding Communities & 11 \\
2. Decision makers & Rwanda Development Board & 3 \\
3. Conservation NGOs & Local Government & 3 \\
4. Media & Wildlife Conservation Society & 2 \\
Total & Radio Rusizi & 1 \\
\hline
\end{tabular}

The main analytic tool used to compare the level and quality of community participation with theoretical indicators and core values of the participation was the "Effective participation processes Chart" [36] which has been adapted to take into consideration the case study specificities (Figure 2). 


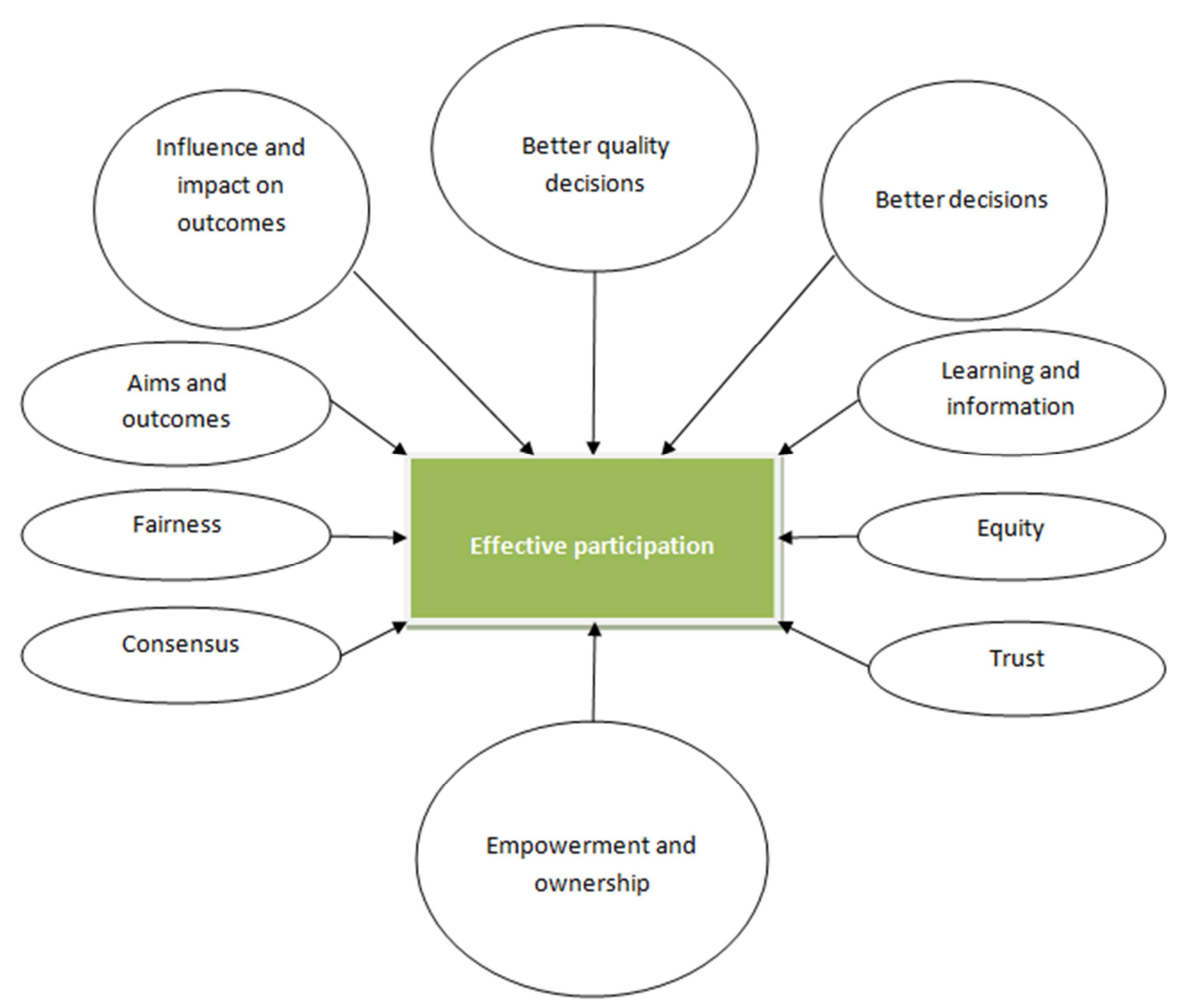

Figure 2. Effective participation processes Chart (Adapted from [36]).

The study was carried out in 3 zones bordering the NNP: (1) Kitabi Sector in Nyamagabe District, (2) Nshili zone in Nyaruguru District and (3) Rusizi headquarters in Rusizi District (Figure 1). The 3 locations were chosen purposively due to their specific needs in terms of conservation. Nshili zone is an ecologically sensitive zone of bamboo habitat predominantly. Kitabi is one of the currently most used tourism zones with activities adjacent to main intensity road crossing the park. It also includes other activities such as tea plantations, Tourism school and major towns. Rusizi District is another important stakeholder with 5 sectors and a convergence of possible tourist sources from neighboring countries, DRC and Burundi.

The data collected or the contents of interviews were transcribed, translated and analyzed using content analysis methods [33]. Deductive codes were developed from existing literature were incorporated in software MAXQDA that analyses qualitative data to make the coding process easier. Inductive codes that were coming out as new information from the data were also incorporated in the coding system.

\section{Results}

\subsection{New Management System and Park-Periphery Interactions}

The comparison between the new law based management and the situation prior to the present day management showed that before the erection of Nyungwe Natural Reserve into NNP, the population entered the forest no matter how in different activities like mining, woodcutting, timber, medicine, honey collection, poaching of animals and searching lands for cultivating. These activities were not illegal because local communities considered the forest as their own heritage. The new governance mechanisms set up by the law comprises intern mechanism and extern mechanism. On one hand, intern mechanisms include field staffs who are the implementers and law enforcers.

On the other hand, the extern mechanism comprises the regulators or planners and controls external actions. For example, the RDB (Kigali staff) is the one which controls regulator guidelines. One of the key meetings in the system brings together different stakeholders on the invitation of the RDB for annual assessment of the management of the park. RDB presents reports of the activities, challenges and problems they faced and how they addressed them; the projects funded etc. The community representatives don't have any information and don't attend the meeting because all processes are under the control of RDB.

The level of participation of local communities is still low for many reasons. The community participation remains only of procedural kind (electing local leaders at the village, cell and sector levels) and through cost-sharing i.e. local taxation 
to pay for services and communal labor sharing. More substantive participation through engaging in planning processes, community agenda prioritization and decisionmaking is all but missing.

\subsection{Understanding of the Community Participation}

\subsubsection{Park's Governance System and Tourism Revenue Sharing}

The NNP management structure under RDB staff authority consists of Chief Park Warden having an overall authority, 3 community conservation wardens responsible for community outreach programs. The management mechanisms consist of RDB staff in Central Office; a District Officer in charge of Environment and an Officer in charge of the environment in the Sector. At Cell and Village levels, the persons responsible for the environment are the Conservation Animators (ANICO), full time volunteers and opinion leaders within the community who provide all information about the parks.

Annually, 2 to 3 meetings enlarged to judiciary and security bodies are organized by RDB. The annual management meeting brings together all the districts bordering the Parks to discuss the reports of management. However, one can say that the local communities are represented by district officers and executives of Sectors who may speak on their behalf. The role of the communities is a key to the success of the new management based on the prevention of illegal activities.

The strategy that has been used by RDB is to group and mobilize the population into associations according to their respective keen activities, then to build their capacity in elaborating and presenting projects for funding. WCS and RDB officers of NNP play the role of mediators between the communities and funding agencies including Savings and Credit Cooperatives (SACCO) and other funding agencies, like Microfinance Institutions such as Réseau Inter-Diocésain des Micro-Finances (RIM) of Roman Catholic (Gikongoro).

The tourism revenue sharing allocated to NNP and its surrounding Districts stakeholders has been continually increased. For example for the Rusizi district it was 38824 US\$ in 2015-2016 and 54539 US\$ in 2016-2017. In July 2018, RDB donated 10 modern housing units worth 42353 US\$ to families that had previously lived in the buffer zone of NNP to improve their livelihood.

\subsubsection{Types and Opportunities of Community Participation}

The mobilization and organization of the population under RDB and conservation NGO's empowerment achieved a number of goals such as: (1) community joint patrols for conservation; (2) organization of cooperatives and associations for mutual empowerment and collective responsibility; (3) revenue injection in local development and improved well-being; (4) consultative processes for development projects; (5) revolving fund and (6) Nyungwe Nziza Project. In concrete terms, the community members participate in wild fire fighting, identifying their own needs; in joint patrol program, removing traps in the park, giving information and working with researches and carrying luggage of tourists.

From the point of view of the conservationists, this community participation system helps to measure changes through the program called RBM which helps to know where traps are located and the number of traps removed in the park. RDB can then be able to know which wild animals were killed and report the incidence. Irrespective complains expressed from some individuals and development projects help to transform the well being of the community members, a boost to social transformation. At the same time, community members move to organised productions for market through cooperatives. Nyungwe Nziza project was created to strengthen sustainable eco-tourism in and around NNP.

It is benefiting the communities with employment generation which is providing economic incentives to reduce threats to the Park and conserve its rich biodiversity. Local communities find more jobs within NNP such as trails clearing and others described above. They also find market for their products such as handcraft products and money easily for their projects through the revolving fund program. The revolving fund scheme develops the community around the park and has transformed the Nyungwe forest into a highly protected National Park. Due to the abandonment of illegal activities, a chance is given to benefit from the revenue sharing scheme.

In the first instances, some families received direct non reimbursable incentives, cash, account opening; cow and other domestic donations. Many others were paid for different works like surveys they were recruited to be involved in. This scheme was completed because it could no longer continue. This study recorded that all the families of some administrative entities benefited from the early move of the new approach with the above mentioned actions undertaken in their favor. However, it is the mentality of the people of the region that needs to change. They all expect aids for free instead of working hard to use the funds available in lending institutions that work with them like SACCO and Catholic Microfinance Network (RIM).

Instead of providing aid for free, both the RDB and WCS are closely working together to connect the population to lending institutions including SACCO and Gikongoro Roman Catholic Microfinance. Different cooperatives and associations made of former Nyungwe forest users move in borrowing money from RIM.

Upon passive over the responsibility to RDB, they now focus on empowering local communities working with the new managers of the Parks (RDB and Districts) to promote cooperative spirit and entrepreneurship among the community members. All together, 24 Sectors bordering the NNP are the targets for capacity building on how to elaborate financially sustainable projects and how to manage the loans. They negotiate with financial lenders like Gikongoro Diocese Microfinance, having abandoned the idea of working with SACCO because of their lack of experience in working with communities.

The target groups comprise beekeepers, tree cutters for 
carpentry; bamboos cutters for different handcrafts; hunters; miners; grass cutters; farmers and others. Whilst its operational costs are funded from the USA, WCS may help communities to elaborate projects that would fit in the funding from many different schemes and funding agencies including RDB.

\subsubsection{From Forest Free Use to Self-Reliance: Cooperative Associations at Cross-Road}

The study showed that the main reasons which contribute to the slowness of the smooth transfer of management are: (1) the slow change of mindset, (2) the geography of the region that unfits for farming which is the most common activity for rural Rwandans and (3) the unaffordable lending conditions of the lending agencies, to mention just a few. Reference made to the slow change of mindset, people in the region have taken for granted the life depending of the free access to the NNP resources.

Next to the period of the inauguration of the law preventing them from illicit use of the park, they were given direct aid. This cannot go on forever and people have to work hard to earn their existence. Among the privileges, we noted the presence of many NGOs that did not exist before and working for empowering communities through capacity building and access to funding. The study showed a big deal of communication and misunderstanding on the interpretation given to the tourism revenue sharing approach.

For instance, the hunters association never received any incentives in compensation of withdrawing from the forest and of associating to prevent anybody from returning to the forests. This should be the reason why poaching is still going on at a high level. Of the view of the park staff, members of the associations are hard to handle because of the receiving mentality many of the bordering community members have and the non-observance of the counseling about the management principles of cooperative associations. Once they have received money, they don't use it to address the issue the funding was provided for.

Regarding unaffordable lending conditions, reports of cooperative associations focused on how their members borrowed the money available for them in the financial lending institutions mentioned above. The cooperative associations meet different challenges with regard to the loans. Recurrent issues of concern for the members of the cooperatives include: (1) the high size of equity announced to be $10 \%$ initially and made $20 \%$ at the time of application, (2) the lack of guaranty or insufficient guaranty, (3) the unpaid loan from other lending institutions, (4) the short period of loan which was reduced to 6 months from 12 months announced at the time of the sensibilisation, (5) the high rates of interest (19\%); and (6) the joint responsibility for bad borrowers that locks up the whole group when a member of the group is insolvable.

Given the fact that most of the projects like agricultural based ones take more than 6 months to generate income, members of the associations resolved to never take the loans instead of exposing their family earnings and properties to being repossessed by the lending institutions. In addition, many members of the cooperatives don't have properties or earnings to give as guaranty for the loan. Others have no property documents which disqualify them from a financial institution loan. Some members of a cooperative may have loans from other lending institutions. In that case, fear to accumulate debt beyond their reimbursement capacity prevents them from taking a loan. Also relevant in this category, poor credit record for some members of a cooperative.

If one member of a cooperative association did not reimburse any loan they received from a financial lending institution, the chance for the whole association to obtain a loan is null. This seems to be a collective punishment, but it was explained that collective responsibility was promoted as mutual empowerment and community collective responsibility for society and the conservation. Despite this somber picture, there are some success stories.

For instance, some members of Twitezimbere cooperative took the loans and managed to pay well and to apply for more. Nine (9) out of its sixteen (16) members took a loan of 1824 SUS and reimbursed it within the 3 months they gave themselves yet they still accompany two of their colleagues who ought to pay off 45 \$US. Ten (10) out of its sixteen (16) cooperative members took a loan of 1718 \$US which they invested in farming and have completed the reimbursement.

\subsection{Challenges Facing the Tourism Revenue Sharing Approach}

The TRS approach is facing many challenges related to the insufficient of natural resources and the rising population pressure. The level and degree of community participation is channeled through the RDB management dynamics. RDB calls for proposals of projects from the community through different cooperatives and associations. Once projects are accepted they are given funds basing on the priorities. RDB is also in charge of teaching cooperatives members how to design, to execute and to manage good projects through different processes of capacity building. The RDB staff informs the community on different stages of projects elaboration and when to submit their projects for funding.

Funding typically goes mainly to those communities that pose the biggest threats to the park. The programs funded by the Tourism Revenue Sharing mechanism are about improving people's lives and to preserve biodiversity. The project implementation is enhanced through local labor and knowledge. The projects are planned by the Sectors taking into consideration the needs of the local communities. RDB informs the districts of the budget allocated to them and the districts invite their sectors to present projects which are selected at district level. In fact, being the lowest body which deals with public accounts audit, the district is the local entity to receive and manage the money to funding projects presented by Sectors.

The new management approach is welcomed and praised by many observers. According to district officers, the elaboration of projects at the Sector level is well informed of 
the community needs by those who know them better. There are lots of new initiatives including schools that were recently inaugurated in Sectors like Gisakura, Cyamudongo and Butare. The collaboration between RDB and WCS in smooth transfer of the management and in organizing radio programs they broadcast on the revenue sharing plans helps to raise the awareness of the population over the conservation and preservation of the park.

However, there are dissent voices from some members of the community. According to them, they are some concerns over a number of challenges. Firstly, through the new approach, the top-down management model is perpetuated by the dominance of the RDB in the definition, the implementation, the monitoring and the evaluation of policies. Even the local government authorities are informed; not considered full entitled stakeholders.

They are informed of the budget allocated to district and invited to present projects for funding, and then supervise the elaboration and the implementation of funded projects. Secondly, the fact that the funding supports the projects planned by the districts including housing, education, health and infrastructures, management projects help the district to perform well in Imihigo (District performance contracts) instead of benefiting directly to individual families. Given the fact that local families and community members do not receive direct incentives in compensation to their withdrawal from the Park, they ask what difference the new system does have compared to the districts where the population does not depend on the forest.

After all, the government, in its mandate, is financing similar projects in other districts. Thirdly, the community members are almost absent in the monitoring and evaluation of the processes. In the annual management meeting, not only the population is not represented, but also the district is not well informed of who the RDB invites in the meeting and on which basis.

\subsection{Challenges Facing the Conservation Programs}

Since the implementation of the new management approach, poaching for meat and money remains the main illegal activity that NNP is facing now at a high level. Mining is no longer a big issue because the rate is coming down. In various occasions poaching result from conflicts between humans and wild populations because animals go out to raid crops of the community and injure sometimes community members. These tensions pushed the government to create a compensation fund which pays for crops that are damaged on the basis of field pictures, assessment of damages by agronomists and forms for compensation. However, victims who experienced this process found it slow and complicated. Some never take the step to report to the Sector's staff and to RDB where applications are signed in order to have and take all the documents to Kigali where the Compensation Office is located.

This process is constantly denounced by the population as long, complicated, expensive and confusing for rural populations who have to report to big City like Kigali where they have not been before, spending nights and days for services that are slow to come. The consequences are many including no-cooperation of the community and increased traps that kill animals instead of conservation. Adding to that, the Tourism Revenue Share comes late for the budgeting process in district to take them into consideration. The exact amount of the allocation is communicated by midterm budget revision and yet that the amount is not transferred until the end of the fiscal year. Therefore, the allocation cannot be put in the planning and is always moved to the next fiscal year. This handicap the execution of the projects planned.

\subsection{Community Participation and Information Exchange}

Good communication upward and downward is a key to the success of sustainable conservation and preservation through community participation. The local communities are accountable for their projects. This has been a gradual change from individuals to the whole society. Individuals will be accountable for the projects conceived by themselves but through community. On the other side, the Park management staff follows up and participates in project selection and approval. The Park management provides funds for community as beneficiaries but they are responsible for monitoring the use of that money.

Persistent exchange of information and communication lead community members to contribute to the formulation of management plans, the project evaluation and the biodiversity monitoring. At the stakeholders' annual meeting, the community sends representatives who take information back to him. In other meetings the Cell or Sector staffs attend and provide information regarding the park. Media reports and programs on environment protection and conservation are part of the strategy promoted through talks on Radio Rusizi and Radio Salus. Gradually, the community understands the role of the forest and parks.

In the past people valued the forest in terms of mining activities, timber and poaching. Today, they know the role that NNP is playing in generating income for community projects. The collaboration between NNP and the community is the one way to achieve the sustainability of the community well-being and of the protection.

\section{Discussion}

As it has already been mentioned previously, the community based conservation process is slow and low. The weak performance of the new approach is due to the lack or insufficiency of fairness, consensus, learning and information, influence and impact on outcomes and aims and outcomes as indicators of effective participation [20, 19, 15]. Sharing tourism benefits with local communities has always been a controversial issue whatever approaches of community participation in tourism industry are involved [37].

Although tourism can generate considerable benefits, it is facing inequitable distribution of costs, benefits and power among different actors on different scales and the 
insignificant economic impacts at local destinations. Defenders of TRS philosophy argue that it promotes tourism development and ensures that local communities enjoy tangible benefits from the industry while participating in wildlife conservation. It rings good positive impact on community attitudes towards conservation of national parks [38]. Wherever the people were considered without a voice in the development process of TRS, they threatened the sustainable tourism development and put in jeopardy the involvement and participation of the community [39].

Many ICDPs implementers are failing to meet the social and economic dynamics of the resources use in the areas and therefore the real threats to biodiversity are not recognized and not correctly addressed [9]. The great dependency on natural resources can be explained by the low agriculture income, limited access to job opportunities, food insecurity, illiteracy and large size of local families ( $>6$ people per household) among other things [24]. As it appears, the RDB central and field staffs play key roles in the regulatory system and processes and in the control.

The new law seems to give no room for community association participation, independent bodies like the WCS and local governments as part of the RDB mechanisms of the Park management even if this does not meet the point of view of RDB. As [15] found it, through TRS system communities are the primary actors in conservation program. They are empowered and involved through awareness raising and education. The process of mediation played by RDB is subject to some questioning of members of the community and observers who consider that the community members are not included in the identification of the projects that meet their needs nor involved in the monitoring and evaluation of the park management.

The new approach is a downward driven process given the fact that NNP is a state owned and controlled park and not a co-managed protected area. This questions on the sincerity, the effectiveness and the sustainability of the community based conservation according to the criteria of such approach $[15,19,20,40]$. The TRS approach has a positive and significant impact on the reduction of illegal activities except poaching. This situation carries a risk of encouragement of park depending people to commit illegal activities given the fact that their real interests and full participation are not enough taken into account.

The delay in money transfer can be overcome with some consultation between the stakeholders because if a district delays reporting, all other districts are penalized. This is a collective punishment which can fairly be resolved by collective responsibility through both shaming and mutual assistance to the defaulting district.

\section{Conclusion}

The study showed that the recent policy of community participation in the management of NNP has brought new perspectives and hope for sustainable conservation. Many conservation NGOs have moved to work along the populations to empower them and accompany initiatives, entrepreneurship and projects that overturn their eternally depending on the natural resources of NNP. Even if we note contrasted appreciations of the strategy according to the category and the position of stakeholders, it is obvious that 13 years on from the inauguration of the new management system of the NNP, the transition process towards self-reliance of the communities bordering the park is slow.

The new philosophy of socio-economic development for the communities based on grouping them in cooperative associations and empowering them to move for borrowing money for projects funding is also slow. Still the top down management model is not significantly beyond the horizons. $\mathrm{RDB}$ is orchestrating much of the processes including the definition of the policies, the monitoring and evaluation of the revenue of tourism and the organization, the planning and the supervision of the management meetings.

Despite the increasing importance of the tourism revenue shared to the local communities, community members still believe that most of the projects presented and funded by the revenue are state and district oriented to achieving Imihigo or District performance contracts, instead of community direct empowerment and well-being improvement. Much education is needed to link the projects with the well-being and transformation of the life of local populations. Equally, an effort is needed for the local communities to be fully involved in the processes of project definitions and elaboration, project monitoring and implementation and park management meetings.

RDB should develop a clear and real community-based conservation approach that will see communities around NNP region actively participate in the decision making process of activities related to tourism and conservation. Using the theoretical criteria for effective community participation, RDB should promote an interactive participation approach where people, including local communities, local governments and RDB itself will collaborate and participate together in the development of action plans and structure or strengthening of local institutions.

Adding to that, RDB should develop mechanisms that empower local communities in increasing skills otherwise some of the local communities will only participate through consultations. With regard to the credits and loans given by financial lending institutions, the rate is clearly beyond the affordability of local communities and need to be fairly decreased. The duration should be increased and flexibility allowed over collective responsibility. Individuals should respond on their own instead of penalizing all members of the cooperative associations. Additionally, to allow communities members to face the lack of properties or earnings and the lack of property documents to be given as guaranties for the loan application process, RDB should initiate a guaranty fund program in the favor of those vulnerable people, using part of the available funds. 


\section{References}

[1] Adams, M. W. and Infield, M. (2003). Who is on the Gorilla's Payroll? Claims on Tourist Revenue from an Ugandan National Park. World Development 31 (1): 177-190.

[2] Western, D. and Wright, R. (1994). Natural Connections; Perspectives on Community- Based Conservation. Island Press, Washington DC.

[3] Mugisha, A. (2002). Evaluation of community based conservation approaches: management of protected areas in Uganda, University of Florida, Nantonga, USA.

[4] Jones, Samantha. (2006). "A Political Ecology of Wildlife Conservation in Africa."Review of African Political Economy no. 33 (109): 483-495.

[5] Songorwa, A. N. (1999). Community-based wildlife management (CWM) in Tanzania: Are communities interested? World Development, 27 (12) 2061-2079.

[6] Holland, T. G., Peterson, G. D. \& Gonzalez, A. (2009) A cross-national analysis of how economic inequality predicts biodiversity loss. Conservation Biology, 23, 1304-1313.

[7] Hulme, D. and Murphree, M. (2001). African Wildlife and Livelihoods: The Promise and performance of Community Conservation James Currey Ltd. Oxford.

[8] Mehta, J. N., \& Heinen, J. T. (2001). Does community-based conservation shape favorable attitudes among locals? An empirical study from Nepal. Environmental management, 28 (2), 165-177.

[9] Lele, S. et al., (2010). Beyond exclusion: alternative approaches to biodiversity conservation in the developing tropics. Current Opinion in Environmental Sustainability, 2 (1-2), pp. 94-100.

[10] Gbadegesin, A. and O. Ayileka. (2000). Avoiding the mistakes of the past. Toward community oriented management strategy for the proposed national Park in Abuja- Nigeria. Land use Policy 17: 89-100.

[11] Mabunda, M. D. (2004). Historical overview of tourism development in the KNP.

[12] Kumasi, T. C., Obiri-Danso, K., \& Ephraim, J. H. (2010). Community engagement in the sustainable management of rivers: Barekese catchment, Kumasi, Ghana. Environment, development and sustainability, 12 (6), 927-943.

[13] Fabricius, C., Koch, E., Turner, S., \& Magome, H. (Eds.). (2013). Rights resources and rural development: Communitybased natural resource management in Southern Africa. Routledge.

[14] Salafsky, N. \&Wollenberg, E. (2000) Linking livelihoods and conservation: a conceptual framework and scale for assessing the integration of human needs and biodiversity. World Development, 28, 1421-1438.

[15] Reed, M. S., Fraser, E. D. G., Dougill, A. J., 2006. An adaptive learning process for developing and applying sustainability indicators with local communities. Ecological Economics 59, 406-418.

[16] Estrella, M., Gaventa, J., 2000. Who counts reality? Participatory Monitoring and Evaluation: a literature review.
IDS Working Paper 70, Institute of Development Studies, Brighton.

[17] Reed, M. S., Dougill, A. J., Taylor, M. J., 2007. Integrating local and scientific knowledge for adaptation to land degradation: Kalahari rangeland management options. Land Degradation and Development 18, 249-268.

[18] Binot A. et Joiris D. V. (2007). Règles d'accès et gestion des ressources pour les acteurs des périphéries d'aires protégées. VertigO - la revue électronique en sciences de l'environnement [En ligne], Hors-série 4 | novembre 2007, mis en ligne le 11 novembre 2007, consulté le 21 avril 2016. URL: http://vertigo.revues.org/759; DOI: 10.4000 /vertigo. 759 .

[19] Binot A. (2010). La Conservation de la Nature en Afrique Centrale. Entre Théories et Pratiques. Des Espaces Protégés à Géométrie Variable. Thèse de Doctorat, Université Paris 1 Panthéon-Sorbonne, $444 \mathrm{p}$.

[20] Laslaz L. (2010). Parcs nationaux de montagne et construction territoriale des processus participatifs. Revue de géographie alpine/Journal of Alpine Research Vol. 98, 19p.

[21] Kapoor, I., (2001). Towards participatory environmental management? J. Environ. Manag. 63, 269 et 279.

[22] UNDP, 'Turning Vision 2020 into Reality: From Recovery to Sustainable Human Development. National Human Development Report', Kigali, 2007.

[23] FAO, (2005). Negotiation and mediation techniques for natural resource management by Antonia Engel and BenediktKorf.

[24] Masozera, M. K. (2002) Socio-economic impact analysis of the conservation of the Nyungwe Forest Reserve, Rwanda. MSc thesis, University of Florida, Gainesville, USA.

[25] Munene Ndereba, I, 2017, "The movement for communityled development. Lessons from Rwanda. Retrieved from https://communityleddev.org/2017/06/27/lessons-fromdecentralization-in-rwanda/

[26] REMA, (2015) Study to establish a national list of threatened terrestrial ecosystems and species in need of protection in Rwanda. Kigali, Rwanda.

[27] ORTPN, (2005). Tourism Revenue sharing in Rwanda. KigaliRwanda.

[28] RDB, (2012). Nyungwe National Park Management Plan 2012-2021.

[29] Kurt, A. K. and R. A. Fimbel (1994). Gold mining Activities within the UGZ 4 Management Zone Nyungwe Forest Reserve, Rwanda. Nyungwe Forest Conservation Projet.

[30] REMA, (2015) Study to establish a national list of threatened terrestrial ecosystems and species in need of protection in Rwanda. Kigali, Rwanda.

[31] Mulindahabi, F. \& Ndikubwimana, I. (2010) Monitoring Threats to Biodiversity in Nyungwe National Park, Rwanda. Ranger-based Monitoring Report Year 2010. Wildlife Conservation Society Rwanda and Rwandan Development Board Tourism \& Conservation, Kigali, Rwanda.

[32] Patton, M. Q. (2002). Qualitative Research and Evaluation Methods. Thousand Oaks: Sage. 
[33] Savin-Baden, M. \& Major, C. H. (2013). Qualitative research: The essential guide to theory and practice. London \& New York: Routledge.

[34] Silverman, D. (2014). Interpreting qualitative data $\left(4^{\text {th }}\right.$ Ed.). Los Angeles, London, New Delhi, Singapore \& Washington DC.: SAGE.

[35] MacMillan, J. \& Schumacher, S. (2014). Research in education: Evidence-based inquiry $\left(7^{\text {th }}\right.$ Ed.). Harlow: Pearson Education Limited.

[36] Reed, M. S., 2008. Stakeholder participation for environmental management: a literature review. Biol. Conserv. 141,2417 and 2431.

[37] Tosun, C. (2000). Limits to community participation in the tourism development process in developing countries, Tourism Management, vol. 21. 613-633.

[38] Archabald, K. and Naughton-Treves, L. (2001). Tourism revenue-sharing around national parks in Western Uganda: early efforts to identify and reward local communities, Environmental Conservation, 28 (2) 135-149.

[39] Havel, V. (1996). The World Bank Participation Sourcebook, the World Bank. Available: http://www.worldbank.org/wbi/sourcebook.

[40] Borrini-Feyerabend G., Dudley N., Jaeger T. and al. (2013). Governance of Protected Areas: From understanding to action. Best Practice Protected Area Guidelines, Series 20, Gland, Switzerland: IUCN, xvi, 124p. 